\title{
Ekotoksikoloji Alanında Balık Hücre Hatlarının Kullanımı
}

\author{
Aylin Pehlivan, Enes Atmaca, Abdurrahman Aksoy
}

Geliş Tarihi / Received: 14.11.2018, Kabul Tarihi / Accepted: 30.11.2018

\author{
Ondokuz Mayls Üniversitesi, Veteriner Fakültesi, Veterinerlik Farmakoloji ve Toksikolojisi AD, Samsun
}

\begin{abstract}
Özet: Son y1llarda, pratik ve etik nedenlerle, ekotoksikolojide in vitro yöntemlere olan ilgi artmıştır. Sitotoksisite çalışmalarında hücre kültürü uygulamaları, in vivo çalışmalardan elde edilen sonuçlara uyumluluğu ve hücresel düzeyde inceleme olanağı gibi avantajlarıyla, diğer in vitro yöntemlere göre öne çıkmıştır. Balık hücre kültürleriyle yapılan çalışmalar, kimyasal maddelerin toksik ve çevresel etkilerinin değerlendirilmesine imkan sağlamaktadır. Ekotoksikolojide, kimyasal maddelerin toksik ve çevresel etkilerinin değerlendirilmesinde RTG-2, RTL-W1, PLHC-1 ve EPC gibi çeşitli balık hücre hatları sıklıkla tercih edilmektedir. Bu derlemede, balık hücre hatlarının ekotoksikoloji çalışmalarında kullanımları ve dikkat edilmesi gereken bazı hususlar ele alınmıştır.
\end{abstract}

Anahtar Kelimeler: Çevresel kirleticiler, ekotoksikoloji, balık hücre hattı

\section{Use of Fish Cell Lines in Ecotoxicological Researches}

\begin{abstract}
In recent years, interest in in vitro methods for ecotoxicology has increased considerably for practical and ethical reasons. Cell culture applications have many advantages such as compatibility with the results obtained in in vivo studies and the possibility of examination at the cellular level. Ecotoxicological studies with fish cells provide the assessment of toxic effects of both chemical substances as well as environmental samples. A variety of fish cell lines such as RTG-2, RTL-W1, PLHC-1, and EPC are frequently preferred in the evaluation of toxic and environmental effects of chemical substances in ecotoxicology. In this review, the general characteristics of fish cell lines used in toxicology, their use in ecotoxicology studies and the important points in toxicological evaluation are discussed.
\end{abstract}

Keywords: Environmental contaminants, ecotoxicology, fish cell line

\section{Giriş}

Ekotoksikoloji araştırmalarında balık hücre hatları son yıllarda giderek önem kazanmaktadır. Balık hücre hatları ile yapılan ilk çalışmalar ağırlıklı olarak, viroloji araştırmaları için gökkuşağı alabalığ 1 gonadından türetilmiş bir hücre hattı olan RTG-2 ile başlamıştır. Günümüzde ise kaynağını çeşitli tür ve dokulardan alan, çok sayıda balık hücre hattı, immünoloji, toksikoloji (çevre toksikolojisi), endokrinoloji, biyomedikal araştırmalar, hastalık kontrolü, biyoteknoloji, su ürünleri yetiştiriciliği ve radyasyon biyolojisi gibi pek çok alanda kullanılmaktadır $[18,28]$.

Rachlin ve Perlmutter [35] 1968'de yass1 kafalı golyan balığından (FHM) türetilmiş bir hücre hattında çinkonun sitotoksik etkisini ölçerek, balık hücrelerini toksikoloji alanında kullanan ilk araştırmacılardan olmuşlardır. Bununla birlikte, 1980'lerden itibaren balık hücre hatları, toksikoloji alanında daha yaygın bir şekilde kullanılmaya başlanmıştır. Günümüzde toksikolojik deney ve testlerde balık hücre hatlarının kullanımı, hem bazal hem de spesifik (hücreye özgü) sitotoksisite, genotoksisite, biyotransformasyon, biyobelirteçlerin indüksiyonu ve toksisite mekanizmaları ile ilgili çalışmalar da dahil olmak üzere hücreye özgü fonksiyonlar ve parametreler üzerindeki etkilere yoğunlaşmıştır [14] $\mathrm{Bu}$ derlemede, balık hücre hatlarının ekotoksikoloji çalışmalarında kullanımları ve dikkat edilmesi gereken bazı hususlar ele alınmıştır.

\section{Ksenobiyotikler}

Ksenobiyotik bileşiklerin toksisitesinin değerlendirilmesinde RTgill-W1 [17, 38], RTL-W1 [6, 8, 20, 27, 39], RTG-2 [3, 6, 13, 20] ve PLHC-1 [13, $15,21,43]$ sik kullanılan hücre hatları arasındadir. Bunlardan RTG-2 hücre hatt1, Wolf ve Quimby [44] tarafından bir yaşındaki dişi ve erkek gökkuşağı alabalığının gonad dokusundan oluşturulan ilk balık hücre hattıdır. [11, 26]. RTgill-W1, yetişkin gökkuşağı alabalığının solungacından türetilmiş bir epitelyal hücre hattıdır. Bu hücre hattı, serum içermeyen, basit tampon maddeleri tolere edebilmekte 
ve ekstraksiyon gibi işlemlere gerek duyulmadan doğrudan çevre örneklerine (atık su vb.) maruziyet çalışmalarında kullanılmaktadır. RTgill-W1 hücreleri sıkı bir epitelyum oluşturdukları için, hipo- ve hipertonik koşullara karşı oldukça dayanıklı olup, değişen tuzluluk oranlarına rağmen büyümelerine devam edebilirler. Ancak, hücre çoğalmasını baskılayan ve hücre morfolojisini değiştirebilen kortizol maruziyetine karşı oldukça duyarlıdırlar [17, $28,36]$. RTL-W1, dört yaşındaki bir yetişkin erkek gökkuşağı alabalığının normal karaciğerinden türetilmiş, kendiliğinden ölümsüzleşebilen bir karaciğer epitelyal hücre hattıdır. Bu hücre hatt1, indüklenebilir etoksiresolufin-O-deetilaz (EROD) etkinliği ve bu etkinliğin toksikolojik araştırmalarda kullanımı için özel olarak geliştirilmiştir. RTL-W1, daha çok aril hidrokarbon reseptör (AhR) agonistlerini ve CYP1A indüksiyonunu test etmek amaciyla kullanılmaktadır. Bununla birlikte, çeşitli farmasötiklerin ve kozmetik ürünlerinin sitotoksisite ve çevresel numunelerin genotoksisite analizlerinde tercih edilmektedir [36]. Diğer bir devamlı hücre hatt1 PLHC-1, Poeciliopsis lucida'nın hepatoselüler karsinomundan türetilmiştir. PLHC-1, sık kullanılan diğer fibroblast benzeri hücrelere kıyasla, metabolik etkinliklerinin olması ve kolay kültüre edilmeleri gibi pek çok avantaja sahiptir. Bu hücre hatt1, çeşitli kimyasal, kirletici ve çevresel örneklerin akut ve kronik toksisitesini değerlendirmek ve kimyasal maddelerin yapı-aktivite ilişkilerini araştırmak için oldukça uygundur [19].

Benzo(a)piren (BaP), ekotoksikoloji araştırmalarında en çok çalışılan ksenobiyotik maddedir. Bazı hücre hatları, BaP'i suda çözünür ara ürünlere dönüştürmektedir [10]. Bu ara ürünlerden diolepoksitlerin, özellikle pürin bazları olan deoksiguanozin ve deoksiadenozin olmak üzere, DNA'ya bağlanıp genotoksisite ve karsinojeniteye sebep olduğu bildirilmiştir [22]. En çok çalışılan ksenobiyotik enzimi ise, sitokrom P450 üst ailesinin bir üyesi olan CYP1A'dır. Sitokrom P450 gen ailesinin üyeleri, çeşitli ilaçlar ve kirleticiler de dahil olmak üzere lipofilik ksenobiyotiklerin metabolizmasından sorumlu enzimleri kodlamaktadır. CYP1A alt ailesindeki proteinler, prokarsinojenik PAH'lar ve planar-halojenli aromatik hidrokarbonları (PHAH) metabolize eder ve etkinsizleştirirler. CYP3A enzimleri ise, steroid

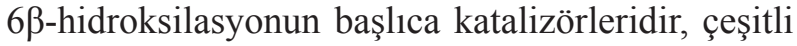

terapötik maddeleri metabolize eder ve aflatoksin B1 ve 7,8-dihidroksi-7,9-dihidrobenzo[a]piren gibi çeşitli prokarsinojenleri etkinsizleştirirler [15].

Behrens ve ark. [8], in vitro modellerin çevresel toksik etkilere karşı verilen yanıtlardaki hücreye özgü farklılıkları araştırmak amacıyla, primer gökkuşağ1 alabalığ1 hepatositleri ile RTL-W1'in PAH'lara maruziyeti sonucu CYP1A indüksiyonunu incelemişlerdir. CYP1A indüksiyonu, EROD aktivitesi ile değerlendirilmiş ve RTL-W1 hücrelerinin, primer hepatosit hücrelerine göre EROD yanıtında daha duyarlı olduğu belirlenmiştir. PLHC-1 ve RTG-2 hücre hatlarında yapılan bir çalışmada 34 farklı farmasötik ürünün toksisitesi, metil tetrazolium (MTT) ve Neutral Red testleri kullanılarak değerlendirilmiştir. Çalışma sonucunda, PLHC-1 hücre hattının bu maddelere, RTG-2 hücre hattından daha duyarlı olduğu ve daha küçük konsantrasyonlarda sitotoksisite gösterdiği ortaya konulmuş [13] ve PLHC- 1 hücre hattının ksenobiyotik maddelere daha duyarlı olmasinın metabolik aktivitesi sebebiyle olduğu bildirilmiştir [19].

\section{Çevresel Östrojenler}

Dioksinler, dikloro difenil trikloroetan (DDT), dietilstilbestrol (DES) ve poliklorlu bifenil bileşikler (PCB) gibi çevresel östrojenler (Environmental Estrogens, EE), doğal yollarla veya insan faaliyetlerinin bir sonucu olarak çevrede ortaya çıkan ve $17 \beta$-östradiol'ün (E2) etkisini taklit ederek endokrin sisteme zarar veren, balıkların üreme ve genel sağlık durumunun bozulmasına neden olan maddelerdir. Östrojen reseptörü (ER), EE'lerin hemen hemen tüm önemli faaliyetlerine aracılık etmektedir. Östrojenik maddeler ya ER aracılığıyla ya da bu reseptörün aracılığına ihtiyaç duymadan, E2 tarafından başlatılanlara benzer hücre veya dokuya özgü etkilere sebep olabilmektedir [2].

EE'lerin incelenmesinde genellikle primer bal1k hepatosit kültürlerinde E2 ile vitellojenin (Vg) indüksiyonu çalışılmıştır. Balık hücre hatlarına genel olarak bakıldığında ise östrojenlere karşı çok duyarlı olmadıkları gözlenmiştir [10].

\section{Dioksin ve benzeri bileşikler}

Dioksin vb bileşikler dermal toksisite, hepatotoksisite, teratojenite, tümörojenite, immüno-toksisite, hormonal ve nörodavranışsal değişiklikler ve ölüme 
sebep olabilmektedirler. Tüm bu etkilerin, bir prototip uyarıc1 olan 2,3,7,8-tetraklorodibenzo-p-dioksin $(2,3,7,8-\mathrm{TCDD})$ aracılığılla olduğu bilindiğinden, benzer tepkileri ortaya çıkaran bileşikler topluca dioksin benzeri bileşikler (Poliklorlu dibenzodioksinler (PCDD), poliklorlu dibenzofuranlar (PCDF) ve dioksin benzeri PCB'ler olarak adlandirılır [12]. Dioksin vb bileşikler AhR'ye bağlanarak CYP1A geninin ekspresyonunda artışa neden olurlar [10].

Dioksin vb bileşiklerden TCDD (dioksin), çoğu omurgalının sahip olduğu AhR'ne bağlanan en toksik bileşiktir [10]. Dioksinin, yükssek dozlarda balıklar, kuşlar ve memeliler dahil birçok hayvan türünde lenfoid doku ve gonadlarda atrofi, hepatotoksisite, nörotoksisite ve kardiyotoksisiteye yol açtığ 1 bildirilmiştir [9]. Bununla birlikte, dioksinin olumsuz etkilerinin oksidatif stres ile ilişkili olduğu ve CYP1A izoformlarının indüksiyonuna yol açarak oksidatif DNA hasarına sebep olduğu belirtilmiştir [10].

RTG-2, RTL-W1, FG-9307 ve PLHC-1 gibi balık hücre hatları, AhR sinyal iletim sistemi tarafindan kontrol edilen genleri ve süreçleri incelemek için kullanılmıştır ve bu hücre hatlarının dioksin vb bileşiklerin toksisitesinin taranmasında uygun bir biyobelirteç olabileceği belirtilmiştir [5, 21, 29, 34].

\section{Ağır Metaller}

A ğır metal kirliliğinin, Minamata hastalığ (organik civa zehirlenmesi), Itai-itai hastalığ (kadmiyum zehirlenmesi), arsenik zehirlenmesi ve hava kirliliği ile ilişkili astım gibi küresel boyuttaki çeşitli hastalıkların nedeni olduğu bilinmektedir. Deniz ekosistemlerinde, kirletici maddeler arasında ağır metal birikimi küresel önem taşımaktadır. Ağır metal kirliliği, su ortamının ekolojik dengesi ve su canlılar1 üzerinde olumsuz etkilere neden olabilmektedir. Ağır metaller, kalıcı ve birikici özellikleri nedeniyle, su canlıları tarafindan su ve sedimentten alınmakta ve düşük trofik seviyelerden daha yüksek seviyelere doğru biyomagnifikasyon şekillenmektedir [7].

Metal homeostazında çeşitli molekül sınıfları yer almaktadır. Glutatyon (GSH) ve metallotiyonein (MT) gibi biyobelirteçler, ağır metal kontaminasyonunu değerlendirmek için sıklıkla kullanılırlar [1]. Glutatyon, hücrelerin zehirli maddelere karşı korunmasında ve ksenobiyotiklerin metabolizmasında yer alan, sülfidrilden zengin bir tripeptittir [10].
Glutatyonun ağır metallere karşı koruyucu etkisinin kısmen bir hücre içi metal şelatörü olarak görev yapmasından kaynaklandığı bildirilmiştir [31]. Metallotiyoneinler ise, memelilerde çinko ( $\mathrm{Zn}$ ) homeostazında işlev gören, organizmayı ağır metal toksisitesi ve oksidatif strese karş1 koruyan, sisteinden zengin metal bağlayıcı bir protein ailesidir. MT-1 ve MT-2 izoformlarının oluşumu, çeşitli metal, ilaç ve yang1 mediyatörleri tarafından karaciğerde hızlı bir şekilde uyarılır. Beyin izoformu olan MT-3 ise, spesifik olarak nöronal büyüme inhibitörüdür [16]. Yapılan bazı çalışmalarda, MT'lerin serbest radikal temizleyici olarak işlev gördükleri ileri sürülmüştür [24]. Başka bir çalışmada ise tek başına MT indüksiyonuna kiyasla GSH ve MT'nin birlikte oksidatif hasara karşı daha etkili olduğu belirtilmiştir [41].

MT'lerin işlevlerini araştırmak amacıyla RTG2, GCF (Grass Carp Fin, Ctenopharyngodon idella), CIK (Cytokine-induced killer), EPC (Epithelioma papulosum cyprini), CCO (Channel Catfish ovary, Ictalurus punctatus), BB (brown bullhead, Ameiurus nebulosus) ve FHM balık hücre hatlar1 kullanılmıştır [10, 24, 42]. CIK, EPC ve CCO hücre hatlarının karşılaştırmalı analizinin yapıldı ğ bir çalışmada, CIK hücrelerinin bakıra en duyarlı hücre hattı olduğu, EPC hücrelerinin krom ve Zn'ya karş1 diğer hücrelere göre daha duyarlı, buna karşıllık CCO hücre hattının kadmiyuma karşı en duyarlı hücre hattı olduğu ortaya konulmuştur. Sonuç olarak, CIK, EPC ve CCO hücre hatlarının potansiyel olarak, su ortamında ağır metallerin akut sitotoksisitesinin değerlendirilmesi için hassas biyolojik belirteçler olabileceği gösterilmiştir [42].

\section{Genotoksik Etkili Maddeler}

Balık hücre hatları çeşitli kimyasalların in vitro genotoksisite araştırmalarında kullanılmıştır. Çoğu ksenobiyotik maddenin genotoksisitesi, hücresel metabolizmalardan etkilenmektedir. $\mathrm{Bu}$ nedenle, hücre hatları arasındaki biyotransformasyon aktivitesi veya DNA onarım kapasitesi farkları, in vitro genotoksisite testlerinin sonuçlarını büyük ölçüde etkileyebilmektedir [32]. Balık hücreleri, memeli hücrelerine kıyasla daha düşük DNA onarım kapasitesine sahiptir. Balıklarda nükleotid eksizyon onarım mekanizmasının aktivitesi memeli hücrelerinde olduğundan daha düşüktür. Bu nedenle DNA hasarına karşı daha duyarlı oldukları düşünülmektedir. 
Balık ve kemirgen hücre hatları ile yapılan deneyler, RTG-2 hücrelerinin bir genotoksin olan 4-nitrokinolin-N-okside karşı memeli V79 hücrelerinden daha fazla duyarlılık gösterdiğini ortaya koymuştur [14].

Çevresel kirleticilerin genotoksik etkilerinin değerlendirilmesinde en sik kullanılan balık hücre hatt1 RTG-2'dir [30, 33, 34, 37]. Bunun yanında EPC hücrelerinin de, genotoksik etkileri değerlendirmek için uygun bir hücre hattı olduğu belirtilmektedir [23].
Yapılan çalıșmalar RTG-2 hücre hattının özellikle çevresel kirleticilerin genotoksisitesinin doğrudan değerlendirilmesinde yararlı olduğunu ancak $\mathrm{BaP}$ gibi etkisini metabolize olarak gösteren maddelerde yetersiz olduğunu göstermektedir. Bu nedenle genotoksisite çalışmalarında daha doğru sonuçlar elde edilebilmesi için balık hücre hattının analizi yapılacak maddenin özelliklerine göre seçilmesi gerekmektedir [32].

Ekotoksikoloji araştırmalarında yaygın olarak kullanılan balık hücre hatları, elde edildikleri türler ve özellikleri Tablo 1'de gösterilmiştir.

Tablo 1. Ekotoksikoloji araştırmalarında yaygın olarak kullanılan balık hücre hatları, elde edildikleri türler ve özellikleri $[4,10,25,40]$

\begin{tabular}{|c|c|c|c|c|c|c|}
\hline $\begin{array}{l}\text { Hücre } \\
\text { Hattı }\end{array}$ & Tür & Doku orijini & Morfoloji & $\begin{array}{c}\text { İnkubasyon } \\
\text { sicaklığı }\end{array}$ & Medium & Kullanım Alanı \\
\hline $\mathrm{R} 1$ & $\begin{array}{l}\text { Oncorhynchus mykiss } \\
\text { Rainbow trout (Gökkuşağı alabalığı) }\end{array}$ & Karaciğer & Fibroblastik & $20^{\circ} \mathrm{C}$ & EMEM, \%10 FBS & $\begin{array}{l}\text { Organik ve inorganik kimyasallar, ağır metaller, } \\
\text { endüstriyel atıklar }\end{array}$ \\
\hline RTG-2 & Oncorhynchus mykiss & Testis, Ovaryum & Fibroblastik & $22^{\circ} \mathrm{C}$ & EMEM, \%10 FBS & $\begin{array}{l}\text { Fenol, benzen, anilin gibi çeşitli kimyasallar, atık } \\
\text { sular, dioksin benzeri bileşikler, ağır metaller, geno- } \\
\text { toksik etkili maddeler }\end{array}$ \\
\hline RT-gill W1 & Oncorhynchus mykiss & Solungaç & Epitelyal & $18-20^{\circ} \mathrm{C}$ & $\begin{array}{l}\text { Leibovitz L-15 } \\
\text { medium, \%10 FBS }\end{array}$ & Çevresel örnekler \\
\hline RTL-W1 & Oncorhynchus mykiss & Karaciğer & Epitelyal & $20-25^{\circ} \mathrm{C}$ & $\begin{array}{l}\text { Leibovitz L-15 } \\
\text { medium, \%10 FBS }\end{array}$ & $\begin{array}{l}\text { Çeşitli farmasötik ve kozmetik ürünler, çevre örnek- } \\
\text { leri, dioksin benzeri bileşikler }\end{array}$ \\
\hline PLHC-1 & $\begin{array}{l}\text { Poeciliopsis lucida } \\
\text { Topminnow (Yüzey sazan balığı) }\end{array}$ & $\begin{array}{l}\text { Hepatoselüler } \\
\text { karsinoma }\end{array}$ & Epitelyal & $30^{\circ} \mathrm{C}$ & EMEM, $\% 5$ FBS & $\begin{array}{l}\text { Organotin bileşikleri, çeşitli fenoller, sülfonik asitler, } \\
\text { çeşitli kimyasallar, çevresel örnekler, dioksin benzeri } \\
\text { bileşikler }\end{array}$ \\
\hline $\mathrm{BB}$ & $\begin{array}{l}\text { Ictalurus nebulosus } \\
\text { Bullhead brown } \\
\text { (Kahverengi yayın balığı) }\end{array}$ & $\begin{array}{l}\text { Bağ doku ve kas } \\
\text { (Posterior gövde) }\end{array}$ & Fibroblastik & $23^{\circ} \mathrm{C}$ & EMEM, \%10 FBS & Ağır metaller \\
\hline $\mathrm{BF}-2$ & $\begin{array}{l}\text { Lepomis macrochirus } \\
\text { Bluegill (Güneş balığı) }\end{array}$ & Kaudal gövde & Fibroblastik & $23^{\circ} \mathrm{C}$ & EMEM, \%10 FBS & Ağır metaller, organik toksik bileşikler \\
\hline CHSE-214 & $\begin{array}{l}\text { Oncorhynchus tshawytscha } \\
\text { Chinook salmon (Kral somon) }\end{array}$ & Embriyo & Fibroblastik & $21^{\circ} \mathrm{C}$ & EMEM, \%10 FBS & Çeşitli kimyasallar, antifouling ajanları, sürfaktanlar \\
\hline EPC & $\begin{array}{l}\text { Cyprinus carpio } \\
\text { Common carp (Sazan balığı) }\end{array}$ & $\begin{array}{l}\text { Epitelioma papu- } \\
\text { losum }\end{array}$ & Epitelyal & $25^{\circ} \mathrm{C}$ & EMEM, \%10 FBS & Ağır metaller, genotoksik etkili maddeler \\
\hline FG-9307 & $\begin{array}{l}\text { Paralichtys olivaceus } \\
\text { Olive flounder (Dil balığı) }\end{array}$ & Solungaç & Epiteloid & $20-25^{\circ} \mathrm{C}$ & $\begin{array}{l}\text { Leibovitz L-15 } \\
\text { medium, \%20 FBS }\end{array}$ & Dioksin benzeri bileşikler \\
\hline FHM & $\begin{array}{l}\text { Pimephales promelas } \\
\text { Fathead minnow } \\
\text { (Yassı kafalı golyan balığı) }\end{array}$ & Bağ doku ve kas & Epitelyal & $34^{\circ} \mathrm{C}$ & EMEM, \%10 FBS & Ağır metaller, çeşitli kimyasallar \\
\hline
\end{tabular}

EMEM: Eagle’s Minimum Essential Medium; FBS: Fetal Bovine Serum

\section{Sonuç}

Çok sayıda yapılan çalışmalarla, ekotoksikoloji araştırmalarında balık hücre hatlarının özellikle çeşitli çevresel kirleticilerin sitotoksisite, genotoksisite, CYP1A indüksiyon potansiyeli ve östrojenik aktivitelerinin değerlendirilmesinde duyarlı ve spesifik in vitro sistemler olduğu ortaya konulmuştur.
Bunun yanında balık hücre hatları ile yapılacak olan çalışmalarda daha doğru sonuçlar elde edebilmek için bu sistemlerin hangi kimyasal gruplara yanıt verdikleri, hangi hücre hattının hangi kimyasala daha duyarlı olduğu göz önünde bulundurulmalı ve kimyasal maddelerin toksik etkilerinin değerlendirilmesinde doğru test metotları seçilmelidir. 


\section{Kaynaklar}

1. Acker LA, McMahan JR, Gawel JE, (2005). The effect of heavy metal pollution in aquatic environments on metallothionein production in Mytilus sp. Proceedings of the 2005 Puget Sound Georgia Basin Research Conference.

2. Ackermann GE, Brombacher E, Fent K, (2002). Development of a fish reporter gene system for the assessment of estrogenic compounds and sewage treatment plant effluents. Environ Toxicol Chem. 21, 1864-1875.

3. Araujo CSA, Marques SAF, Carrondo MJT, Gonçalves $\mathrm{LMD},(2000)$. In vitro response of the brown bullhead catfish $(B B)$ and rainbow trout $(R T G-2)$ cell lines to benzo(a) pyrene. Sci Total Environ. 247, 127-135.

4. ATCC, (2018). Erişim adresi: https://www.lgcstandardsatcc.org/en.aspx , Erişim tarihi: 09.11.2018.

5. Babin MM, Tarazona JV, (2005). In vitro toxicity of selected pesticides on RTG-2 and RTL-W1 fish cell lines. Environ Pollut. 135, 267-274.

6. Babin M, Boleas S, Tarazona JV, (2005). In vitro toxicity of antimicrobials on RTG-2 and RTL-W1 fish cell lines. Environ Toxicol Pharmacol. 20, 125-134.

7. Baby J, Raj JS, Biby ET, Sankarganesh P, Jeevitha MV, Ajisha SU, Rajan SS, (2010). Toxic effect of heavy metals on aquatic environment. Int J Biol Chem Sci. 4(4), 939952.

8. Behrens A, Schirmer K, Bols NC, Segner H, (2001). Polycyclic aromatic hydrocarbons as inducers of cytochrome P4501A enzyme activity in the rainbow trout liver cell line, RTL-W1 and in primary cultures of rainbow trout hepatocytes. Environ Toxicol Chem. 20(3), 632-643.

9. Birnbaum LS, Tuomisto J, (2000). Non-carcinogenic effects of TCDD in animals. Food Addit Contam. 17(4), 275-288

10. Bols NC, Dayeh VR, Lee LEJ, Schirmer K, (2005). Use of fish cell lines in the toxicology and ecotoxicology of fish. Piscine cell lines in environmental toxicology. Mommsen TP, Moon TW. eds. Biochemistry and molecular biology of fishes. Elsevier B.V. p.43-84.

11. Bols NC, Pham PH, Dayeh VR, Lee LEJ, (2017). Invitromatics, invitrome, and invitroomics: introduction of three new terms for in vitro biology and illustration of their use with the cell lines from rainbow trout. In Vitro Cell Dev Biol. 53, 383-405.

12. Brack W, Schirmer K, Kind T, Schrader S, Schüürmann G, (2002). Effect-directed fractionation and identification of cytochrome P4501A-inducing halogenated aromatic hydrocarbons in a contaminated sediment. Environ Toxicol Chem. 21(12), 2654-2662.

13. Caminada D, Escher C, Fent K, (2006). Cytotoxicity of pharmaceuticals found in aquatic systems: Comparison of PLHC-1 and RTG-2 fish cell lines. Aquat Toxicol. 79, 114-123.

14. Castano A, Bols N, Braunbeck T, Dierickx P, Halder M, Isomaa B, Kawahara K, Lee LEJ, Mothersill C, Pärt P, Repetto G, Sintes JR, Rufli H, Smith R, Wood C, Segner
$\mathrm{H}$, (2003). The use of fish cells in ecotoxicology. ATLA. 31, 317-351.

15. Celander M, Hahn ME, Stegeman JJ, (1996). Cytochromes P450 (CYP) in the Poeciliopsis lucida hepatocellular carcinoma cell line (PLHC-1): Dose and time-dependent glucocorticoid potentiation of CYP1A induction without induction of CYP3A. Arch Biochem Biophys. 329(1), 113122.

16. Coyle P, Philcox JC, Carey LC, Rofe AM, (2002). Metallothionein: The multipurpose protein. Cell Mol Life Sci. 59, 627-647.

17. Dayeh VR, Schirmer K, Bols NC, (2002). Applying wholewater samples directly to fish cell cultures in order to evaluate the toxicity of industrial effluent. Water Res. 36, 3727-3738.

18. Fent K, (2001). Fish cell lines as versatile tools in ecotoxicology: assessment of cytotoxicity, cytochrome P4501A induction potential and estrogenic activity of chemicals and environmental samples. Toxicol In Vitro. 15, 477-488.

19. Fent K, (2007). Permanent fish cell cultures as important tools in ecotoxicology. ALTEX. 24(8), 26-28.

20. Fent K, Batscher R, (2000). Cytochrome P4501A induction potencies of polycyclic aromatic hydrocarbons in a fish hepatoma cell line: demonstration of additive interactions. Environ Toxicol Chem. 19(8), 2047-2058.

21. Fent K, Hunn J, (1996). Cytotoxicity of organic environmental chemicals to fish liver cells (PLHC-1). Mar Environ Res. 42(14), 377-382.

22. IARC, (2010). Benzo[a]pyrene. https://monographs.iarc. fr/wp-content/uploads/2018/06/mono100F-14.pdf ,Erişim tarihi: 30.11.2018.

23. Kammann U, Bunke M, Steinhart H, Theobald N, (2001). A permanent fish cell line (EPC) for genotoxicity testing of marine sediments with the comet assay. Mutat Res Genet Toxicol Environ Mutagen. 498(1-2), 67-77.

24. Kling P, Erkell LJ, Kille P, Olsson PE, (1996). Metallothionein induction in rainbow trout gonadal (RTG-2) cells during free radical exposure. Mar Environ Res. 42(1-4), 33-36.

25. Lakra WS, Raja Swaminathan T, Joy KP, (2011). Development, characterization, conservation and storage of fish cell lines: a review. Fish Physiol Biochem. 37, 1-20.

26. Lange M, Gebauer W, Markl J, Nagel R, (1995). Comparison of testing acute toxicity on embryo of zebrafish, Brachydanio rerio and RTG-2 cytotoxicity as possible alternatives to the acute fish test. Chemosphere. 30(11), 2087-2102.

27. Lee LEJ, Clemons JH, Bechtel DG, Caldwell SJ, Han KB, Pasitschniak-Arts M, Mosser DD, Bols NC, (1993). Development and characterization of a rainbow trout liver cell line expressing cytochrome P450-dependent monooxygenase activity. Cell Biol Toxicol. 9(3), 279-294.

28. Lee LEJ, Dayeh VR, Schirmer K, Bols NC, (2009). Applications and potential uses of fish gill cell lines: examples with RTgill-W1. In Vitro Cell Dev Biol. DOI:10.1007/ s11626-008-9173-2. 
29. Li H, Zhang S, (2001). In vitro cytotoxicity of the organophosphorus pesticide parathion to FG-9307 cells. Toxicol In Vitro. 15, 643-647.

30. Llorente MT, Parra JM, Sanchez-Fortun S, Castano A, (2012). Cytotoxicity and genotoxicity of sewage treatment plant effluents in rainbow trout cells (RTG-2). Water Res. 46, 6351-58

31. Maracine M, Segner H, (1998). Cytotoxicity of metals in isolated fish cells: Importance of the cellular glutathione status. Comp Biochem Physiol A.120, 83-88.

32. Nehls S, Segner H, (2001). Detection of DNA damage in two cell lines from rainbow trout, RTG-2 and RTL-W1, using the Comet assay. Environ Toxicol. 16, 321-329.

33. Nehls S, Segner H, (2005). Comet assay with the fish cell line rainbow trout gonad-2 for in vitro genotoxicity testing of xenobiotics and surface waters. Environ Toxicol Chem. (24)8, 2078-2087.

34. Parra J.M, Sanchez-Fortun S, Castano A, (2012). Assessment of genotoxic effects induced by selected pesticides on RTG-2 fish cells by means of a modified fast micromethod assay. Environ Toxicol. 27, 238-243.

35. Rachlin JW, Perlmutter A, (1968). Fish cells in culture for study of aquatic toxicants. Water Res. 2(6), 409-414.

36. Roux F, (2015). Fish cell lines and their potential uses in ecotoxicology: from cytotoxicity studies and mixture assessment to a co-culture model and mechanistic analyses. Master Thesis, Department of Biological and Environmental Sciences University of Gothenburg, Gothenburg.
37. Sanchez P, Llorente M.T, Castano A, (2000). Flow cytometric detection of micronuclei and cell cycle alterations in fish-derived cells after exposure to three model genotoxic agents: mitomycin $C$, vincristine sulfate and benzo(a) pyrene. Mutat Res. 465, 113-122.

38. Schirmer K, Dixon DG, Greenberg BM, Bols NC, (1998). Ability of 16 priority PAHs to be directly cytotoxic to a cell line from the rainbow trout gill. Toxicology. 127, 129-141.

39. Schirmer K, Chan AGJ, Bols NC, (2000). Transitory metabolic disruption and cytotoxicity elicited by benzo[a]pyrene in two cell lines from rainbow trout liver. J Biochem Mol Toxicol. 14(5), 262-276.

40. Schirmer K, (2006). Proposal to improve vertebrate cell cultures to establish them as substitutes for the regulatory testing of chemicals and effluents using fish. Toxicology. 224, 163-183.

41. Schlenk D, Rice CD, (1998). Effect of zinc and cadmium treatment on hydrogen peroxide-induced mortality and expression of glutathione and metallothionein in a teleost hepatoma cell line. Aquat Toxicol. 43, 121-129.

42. Tan F, Wang M, Wang W, Lu Y, (2008). Comparative evaluation of the cytotoxicity sensitivity of six fish cell lines to four heavy metals in vitro. Toxicol In Vitro. 22, 164-170.

43. Thibaut R, Porte C, (2008). Effects of fibrates, anti-inflammatory drugs and antidepressants in the fish hepatoma cell line PLHC-1: Cytotoxicity and interactions with cytochrome P4501A. Toxicol in Vitro. 22, 1128-1135.

44. Wolf K, Quimby MC, (1962). Established eurythermic line of fish cells in vitro. Science. 135(3508), 1065-10. 